\title{
The Awareness Level of Green Procurement at the District Assemblies in Western Region in Ghana
}

\author{
James Adu Peprah ${ }^{1}$, Samuel Brako ${ }^{1} \&$ Noah Boakye Akosah ${ }^{1}$ \\ ${ }^{1}$ Faculty of Business Studies, Department of Procurement and Supply, Faculty of Business Studies, Takoradi \\ Technical University, Takoradi, Ghana \\ Correspondence: James Adu Peprah, Faculty of Business Studies, Department of Procurement and Supply, \\ Faculty of Business Studies, Takoradi Technical University, Takoradi, Ghana.
}

\author{
Received: November 28, 2017 Accepted: January 4, 2018 Online Published: February 3, 2018 \\ doi:10.5539/jms.v8n1p46 URL: https://doi.org/10.5539/jms.v8n1p46
}

\begin{abstract}
The present study seeks to examine the awareness level of green procurement at the district assemblies in Ghana and also help create the consciousness of implementing and enforcing green procurement in the public sector effectively. The research was carried out in Eighteen (18) District Assemblies in the Western Region of Ghana using non-standard interview as the main data collection technique. The findings of the research revealed that, there are key legislations, standards and regulations regulating the assemblies' activities on the environment and the society which affect green procurement, though there is no specific law/policy titled green procurement. These key legislations, standards and regulations have contributed to increased awareness of green procurement at the District Assemblies in Western Region tied with the recent introduction of sustainable procurement which has been included in the Public Procurement Amendment Act 2016 (Act 914). However, the study identified that the significant impact of public procurement as a policy instrument on environment appeared not to be clear to the assemblies. It is recommended that the procurement policy and the Act 663/914 should be reformed to reflect green procurement to help the districts in their quest in creating sustainable environment. The district assemblies and EPA should organise joint seminars and workshops to sensitize and create awareness among the assembly's staff on the benefits of green procurement and the need to adopt it.
\end{abstract}

Keywords: Ghana, Western Region, district assemblies, green procurement, Procurement Act No.663/2003 (Amended Act No 914/2016)

\section{Introduction}

In the recent decades, green procurement activities have taken the central stage of the global discussion of environmental problems (e.g., Walker, Helen, \& Brammer, 2012; Sarkis, Joseph, \& Tamarkin; Chien, \& Li-Hsing, 2007). The motivation for sustainable environmental development is that the planet earth is experiencing a severe crisis originating from various environmental problems such as natural resource depletion, global warming, biodiversity loss etc and it's likely to degenerate due to urbanization, population growth, economic growth, intensification of agriculture, increase in energy use, increase in transportation among others. The efforts both in national and international in endorsing green growth have been intensifying because of its ability towards sustainable development and poverty reduction for instance, more sustainable use of natural resources, efficiencies in the use of energy, and valuation of ecosystem services (OECD, 2012). Green concepts have also the potential to internalise environmental externalities by mainstreaming sustainable development requirements into economic decision-making, notably through resource pricing and land use/infrastructure choices (Ibid). United Nations Environment Programme-UNEP (2011) surmises that there is rising evidence that transitioning to a green economy has sound economic and social justification and posits that governments and private entities should redouble their efforts to engage in such an economic transformation and governments should level the playing field for greener products by phasing out antiquated subsidies, reforming policies and providing new incentives, strengthening market infrastructure and market-based mechanisms, redirecting public investment, and greening public procurement.

Significance of public procurement as a social, economic and environmental tool is immeasurable. For instance, a significant share of the world's GDP is associated with expenditures by governments. On average, total public expenditures by central and local governments (including consumption and investment expenditures) are 
estimated to account for about $20 \%$ of GDP in OECD countries, and roughly $15 \%$ in non-OECD countries. Subtracting compensation to public employees, public procurement is estimated to represent $6 \%$ to $10 \%$ of GDP depending on countries (United Nations Department of Economic and Social Affairs Division for Sustainable Development, 2008). This supports Bobis \& Staniszewski (2009) understanding that procurement's integral role in an organisation's operations makes it the central touch point for all stakeholders, customers, suppliers, subcontractors and service providers to effectively collaborate and build sustainability across the entire supply chain. Linking green to procurement therefore has been seen as one of the extenuating concepts that can help in restoring the degraded environment. The impact of the concept is reinforced by Way (2010) study that using public purchasing power to improve environmental footprint-is a well-established and fast developing concept. It is also gaining momentum as the vehicle of choice for public authorities to manage their environmental impacts and influence business and society to do the same.

Green procurement to Chartered Institute of Purchasing and Supplies-CIPS (2007) is the consideration to the environmental, social and economic consequences of design, materials used (renewable and non-renewable) manufacturing methods, logistics and disposal. The Ministry of Environment-Japan (2012) sees it as the procuring companies' selective purchases of products and services with minimum environmental impacts from environmentally-conscious suppliers. Per the concept-green procurement, the significance stance from the fact that companies generally implement it as part of their value chain management (VCM). The main purpose of VCM here therefore is to reduce environmental impacts and enhance added values, with a view to the entire life cycle of business activities, encompassing raw materials of procurement companies, suppliers and upstream to downstream companies that are involved in the manufacture of relevant products, and also including product use and disposal (Ministry of Environment Japan, 2012). Green procurement is therefore based on the belief that companies or organisations can simultaneously benefit from all the three elements- economics, environment, and society and simply another vehicle for value creation (Bobis \& Staniszewski, 2009). It also has been identified as the capacity to reduce the environmental impacts of government operations and promote environmental goals by integrating environmental considerations in procurement as a part of the government's commitment to improve the environment and the quality of life of its citizens (OECD, 2014). Most organizations are currently pursuing green purchasing policy for its supports on an enterprise economically as well as lighten its environmental aspect. Green purchasing likewise can help organizations improve their efficiency, reduce liabilities, and gain competitive advantage. The fact is that a green purchasing program is an excellent way of finding products with a high price-performance ratio and with improved use rates (Unomaha, 2016).

The promotion of green procurement may have the aptitude in mitigating the various environmental problems, thereby create new business prospects for both governments and corporate entities. However, with such significance, very few studies have shown the awareness level of green procurement among public institutions particularly in less develop nations. Studies have shown that Low Income Countries-LICs generally lack awareness, have no policy, action plans, or implementation of such policies (ORPF, 2014). Within the African context, green/sustainable development is greatly challenged by poverty and other factors such as lack of awareness and lack of appropriate legal frameworks (Economic Commission for Africa, 2012). Besides, Jerry (2000) comments that utilization of green procurement has been quite limited such that a decade ago, only some high-profile organizations mainly chemical firms and/or those firms in the consumer goods sectors that have experienced green consumer pressures directly in order to practice it (Boharia et al, 2015). The issue of this study is that the district assemblies in Ghana with collaboration with the environmental protection agency in protecting the environment and making it sustainable has minimal level of awareness of green/sustainable procurement. The Ghana's Public Procurement Act is relatively new, and capacity and law enforcement very weak in the realm of sustainable public procurement which green procurement is subset (United Nations Environment Programme, 2017). This is supported by ORPF (2014), findings on SPP/green procurement that the LICs do not even have the minimum conditions in terms of awareness of environmental and social problems, a sense urgency, political will, and country ownership to achieve sustainable procurement. For such policy like green public procurement or SPP in general to thrive, the essential policy and legal framework must be put in place, capacity must be built, and the demand and supply sides must understand the new requirements and the applicable techniques. Besides, green procurement has not been directly incorporated by the district assemblies in the execution of their activities in protecting the environment. Intriguingly, Adetunji et al. (2008) disclose that public procurement practices have largely been focused on price, whereas the commitment to environmental issues has been an act of faith rather than a predetermined deliverable (Poon et al., 2004). Similarly, Jaillon et al. (2009) discover that the industries in the district assemblies pays less attention to environmental issues than other issues such as cost of operation and availability of resources. However, the district assemblies currently are becoming more dynamic and innovative as series of projects are being introduced and that awareness of green 
procurement will impact their activities economically, environmentally and socially. Accordingly, the environmental protection does not lie in the care of environmental protection agencies only, but also lies in the care of procurement managers (Chien \& Li-Hsing, 2007). It has been shown from extant literature that green procurement is an essential concept that should be embraced by all organizations and institutions in order to sustain the environment and maintain healthy life (Odeen \& Howard, 2008). Its therefore imperative for this study to empirically look at the awareness level of green procurement at the district assemblies in Ghana by so doing create the consciousness of implementing and enforcing green procurement. The study specifically seeks to identify the nature of key legislature, standards and regulations of green procurement regulation at the district assemblies in Ghana, to also examine the level of awareness of green procurement at the district assemblies, and lastly to examine the challenges facing district assemblies in the awareness creation of green procurement practices in Ghana.

The rest of the paper is organized as follows: section two presents the literature review. Section three discusses the research methodology. Section four deliberates on the data presentation and discussions, section five deals with summary of findings. General conclusions and recommendations for future research are finally presented in sections six and seven respectfully.

\section{Literature Review}

\subsection{Key Legislature, Standard and Regulation of Green Procurement at the District Level}

In Ghana there are various policies, laws and regulations that relate to the environment. There is no clear policy or law specifying green procurement in Ghana's public procurement law but there are a whole lot of laws and policies on land degradations, water bodies, animals among others which are related to green procurement by concept and practices. The concern about the land and environmental degradation has been expressed since the early decades of the twentieth century, notably since the 1930s (Agyepong, 1987; Benneh et al., 1990). Legislation to protect specific aspects and components of the land were put in place in the early years of the century. For instance, in 1901, the Wild Animals Preservation Ordinance was passed, followed by the Rivers Ordinance in 1903. Forest reservation was initiated in 1907, followed a year later by the establishment of the Forestry Department. The Mining Rights Regulations Ordinance was introduced in 1925. Severe degradational problems in the northern savannas led to the institution of land planning and soil erosion measures in those areas. These introduced conservational practices in the agricultural use of land, water, and grazing resources. Planning and execution involved the Departments of Agriculture and Forestry and the local people. The Land Planning and Soil Erosion Ordinance was passed in 1953, and amended in 1957, to create permanent committees of the areas designated for planning (Benneh, 1985). Ghana is the first African country to create AKOBEN, an environmental performance rating and disclosure initiative of pollution by the Environmental Protection Agency (EPA), which provides access to information on the release of mining and other wastes into the environment (Darko-Mensah \& Okereke, 2013). The agency in charge of protecting the environment in Ghana is the Environmental Protection Agency which was called Environmental Protection Council (EPC) then.

The Environmental Protection Council (EPC) was established as a public institution with oversight responsibility for the environment in 1974 through the National Redemption Council Decree, number 239 (NRCD 239) in Ghana. Section 2 of the decree required among other things, the Environmental Protection Council to ensure the observance of proper safeguards in the planning and execution of all development projects including those already in existence that are likely to meddle with the quality of the environment (Yeboah \& Mensah, 2014). The enactment of Environmental Protection Agency Act, 1994 (Act 490) was to create a corporate body called the Environmental Protection Agency (EPA) which replaced the EPC. This agency has been in existence and in charge of environmental issues in Ghana to date. Among its functions, the EPA was mandated to "ensure compliance with any laid down environmental assessment procedures in the planning and execution of development projects, including compliance in respect of existing projects." According to the Environmental Protection Agency, there are Environmental Policy, Sustainable Development Policy and General Legislative Framework. The environmental impacts of the Structural Adjustment Programme (SAP) and Economic Recovery Programme (ERP) in the early 1980s in Ghana led to the development of the Ghana Environmental Action Plan (EAP), a set of policy actions, related investments and institutional strengthening activities to make Ghana's development strategy more environmentally sustainable.

The emerging issues of the environmental challenges currently have assumed prominence and its impact on the economy and society have prompted Ghana to have second view of the public procurement system as a socio-economic instrument in dealing with the environment, society and the economy. The Public Procurement Authority as part of its drive to create an efficient and effective public-sector procurement system that is 
beneficial to the public at large has introduced a new concept, which is about sustainability issues, into Ghana's public procurement (SPP) seeks to address the environmental, social and economic consequences of public procurement actions (Public Procurement Amendment 2016, Act 914). This is in support of the government of Ghana's interest and drive towards sustainable development. Ghana's current pattern of development puts a lot of pressure on the environment. The burdens on the natural eco-systems in Ghana are momentous and if acceptable interventions are not made to change to the contrary the situation, it is likely that the long-term overall effect would be irreversible and catastrophic to future generations.

\subsection{Awareness Level of Green Procurement at the District Assemblies}

The title called green procurement does not exist in Ghana law books or in the public procurement Act 663/the Amendment Act 914 in 2016 though there are other laws, regulations, policies acting in conformity with the tenants of green procurement. The current Public Procurement Amendment 2016 Act 914 contains the concept of sustainable procurement which encompasses green procurement, because of its important impact on sustainable development. Public Procurement Authority has been conducting awareness programmes on new policies such as the framework agreements and sustainable public procurement initiatives; and establishment of two zonal offices in Kumasi and Takoradi to provide advisory services to entities farther away from the capital. As to society overall, the deterioration of the environment over recent decades has drastically increased the public's awareness of environmental issues. Two decades of implementation have brought about some successes including the creation of one hundred and seventy (170) local authorities, the transfer of authority, resources and responsibilities from the center to the local level, awareness-raising amongst the citizenry, infrastructural development with support from the District Assemblies Common Fund and increased collaboration between localities as well as development partners.

With the global awareness on sustainability (Bryde, 2011) there are rising pressures and expectations on a more efficient and value-added deliveries of products and services for their institutional needs (Grönroos, 2006; Walker \& Brammer, 2011; Bryde \& Meehan, 2010). Whether district, region or national, all stakeholders from employees and shareholders to taxpayers and governmental bodies are demanding quality and effective procurement processes and system which can be sustainable (Kalubanga, 2012). As well, Ghana on its awareness creation programs, public organizations, procurement officers and procurement boards from national, regional and districts levels require re-design of standard tender documents, training practitioners of procurement and political support on sustainable public procurement. Government is moving a step further in adopting sound programs and policies of sustainable policies that will achieve greater strides in achieving sustainable procurement (Alliance for Development, 2014). Blome et al. (2013) posit that both top management support and company's market performance leads to the adoption of green procurement. From the district assemblies level, awareness of green/sustainable procurement is very low though there are several efforts from the government in creating the awareness of green/sustainable environment through public procurement.

Green/sustainable procurement plays a role in minimizing any reputation risk of social exploitation within the supply chain. According to UNDP Practice Series (2008) green/sustainable procurement seeks to incorporate a number of safeguards and checks in the procurement process that will assist in guarding against the inadvertent infringement of: labour rights, adverse environmental impacts, supporting local entrepreneurship, gender and the empowerment of women, poverty eradication and governance but traditional procurement mostly focuses on value-for-money considerations. The aim and challenge of green/sustainable procurement worldwide is to integrate environmental and social considerations into the procurement process with the goal of reducing adverse impacts upon health, social conditions and the environment, thereby saving valuable costs for organizations and the community at large but in Ghana the first step needed is the recognition or the awareness of such policy (green/sustainable procurement). Green or sustainable procurement forms a key part of an overall push for sustainable development.

\subsection{Challenges of Awareness Creation of Green Procurement Practices at the District Assemblies}

Awareness creation of green procurement in general has not been easy for nations and organisations even with the developed countries. With the factors of green procurement adoption, one cannot undervalue the possibility that there are some complementary factors which can strongly influence the awareness level of green procurement at any level of development of a nation. This is especially true when a public authority pursues environmental excellence by means of different tools or solutions that are strongly synergetic with (and might suggest the adoption of) green procurement practices. The supply-side of the procurement transaction plays a crucial role in availability of sustainably produced goods and services. Given that some of the goods and services procured by the public sector are highly specialist, it is possible that identifying sustainable sources of supply 
may be very challenging in some contexts (Lysons \& Farrington, 2012). Obstacles to implementing a green procurement program include: lack of readily available environmental friendly products; expensive or zero environmental alternatives; inaccurate studies; lack of organizational support; and inaccurate or unsupported environmental claims by manufacturers and suppliers. Legislation, organizational policies, directives, environmental management systems or multi-lateral agreements often require organizations to implement a green procurement program (Mather, 2010).

Scholars also suggest that financial resource of firms can increase their visibility among external stakeholders. Additionally, financial resource is also considered as a source of organizational slack, in the form of excess resources (Sharma, 2000; Bowen, 2000). Accordingly, superior financial resource could lead to visibility, thereby leading to more pressure from external constituents. External stakeholders could also perceive firms with financial resources to be in a position to use the excess discretionary slack resources to overcome the risk and unpredictability in adopting the proper supply-side environmental practices (Menguc et al., 2010). Recognition of supplier resistance or acceptance is essential for compliance with the procurement rules. To avoid non-compliance all suppliers may be required to provide proof of their commitment to environmental protection. This may take the form of statements on the steps they are taking to reduce their impact on environment, or alternatively to demonstrate that they are not in breach of any statutory requirements relating to the environment (Saunders, 1997). Walker \& Brammer (2009) indicated that the main problem limiting adoption of green public procurement is difficulty in engaging suppliers. Some GPP initiatives were found to be hampered by unwillingness of suppliers to cooperate (Lysons \& Farrington, 2012). This unwillingness could be due to a number of reasons including concerns over sensitive information, poor supplier practices, and resource constraints. Bjorklund (2011) also comments that the extent to which there is support for green procurement at senior levels in an organization and the degree to which organizational processes and structures support retard the development of sustainable procurement. Top management support is critical to the success of either a successfully sustainable procurement strategy or failure of it. Bjorklund (2011) found that priorities among the top/middle management are important drivers in the environmental purchase. Without high level support employees are often unwilling or unable to pursue green procurement initiatives (Ashenbaum, 2008). Ashenbaum (2008) mentioned that in most cases, sustainable procurement is not seen as legitimate or necessary initiatives for upper management or administration to address as the necessary measures are often seen as an added cost with little immediate benefit to the organization.

The other factor challenging the awareness level of green procurement practice could be seen from the lack of trained staff to implement green procurement programs. Too many practitioners, the procurement laws are not explicitly clear and in many case their interpretation is subjective. Therefore, familiarity with the rules by both purchasers and suppliers can influence the chance that public agents will comply with the rules. This leads to the notion that there exists a relationship between familiarity with the green procurement rules and its compliance. Others like Bouwer et al. (2006) found that operational and/or information tools are key in establishing environmental criteria in public procurement while Walker \& Brammer (2009) as well mention lack of information about the real environmental impacts of the products, difficulty in the preparation of call for tenders and purchasing, and lack of guidelines. Gattiker et al. (2008) also establish lack of clear definition and evaluation criteria for green procurement as a barrier. Lack of understanding of how to incorporate environmental issues into buying: Cooper et al. (2000) asserted that, one study found that procurement officers are unsure of how to incorporate environmental issues in their buying. In terms of social responsible buying, it has been observed that: Even when they recognize the relevance of corporate social responsibility, many purchasing managers do not know how to concretely and systematically include social and environmental issues into purchasing decisions. They have little experience with such demands (Maignan et al., 2002).

However, various authors have come out with recommendations as to how to overcome the challenges of creating awareness of green procurement, among them are Bouwer et al. (2006) showing that training and competence in environmental matters is key to successful awareness creation and adoption of green procurement in the public sector. Accordingly, organizational scholars espousing the institutional view of legitimacy (Sharma, 2000), propose that superior financial performance will promote basic supply side environmental initiatives such as green procurement (Shittu \& Bake, 2010). Moreover, investments in development initiatives are far more uncertain than basic green procurement investments. Cost of training has been recommended by many researchers as an effective remedy against environmental illiteracy (Carter \& Dresner, 2001). A study by Bouwer et al. (2006) indicated increased cost of green products compared to those not environmentally friendly as a major barrier to adoption.

In sum, there are whole lot of challenges facing awareness creation on green procurement practice from the lack 
of expertise to lack of government support-reason being that government is responsible for taking the lead in sustainable development, however, little support is provided in the areas of finance, and legal structure to incorporate environmental sustainability issues into construction procurement (Ayarkwa et al., 2010) and the current sustainable procurement in the Public Procurement Amended Act 2016, the gravity of the challenges on awareness creation on green procurement are dire looking at the rate the environment of Ghana is degrading. These challenges are key in embarking on this project to create awareness of green procurement using the district assemblies.

\section{Methodology}

The research methodology adopted for this study is qualitative because of its accommodating element for examining questions like how and why of research instead of calculating exact figures using quantitative methods. It is also because of its comprehensive approach to the studied subject and that the data used is collected in natural, real situations. From Bryman (2001) the preference of a research method depends upon the aim of the inquiry and use of the findings. Its therefore imperative for this study to adopt qualitative method to empirically examine the awareness level of green procurement at the district assemblies in Ghana (Western Region) by so doing create the consciousness of implementing and enforcing green procurement. The study specifically seeks to identify the nature of key legislature, standards and regulations of green procurement regulation at the district assemblies in Ghana, examine the level of awareness of green procurement at the district assemblies, and lastly examine the challenges facing district assemblies in the awareness creation of green procurement practices in Ghana.

Prior to the data collection, meetings were held with key stakeholders at the various districts. During the meetings, the overall purpose of the study was presented, and the participants were informed and prepared for the exercise. Owing to resource and time constraints, fairly small participants were considered for the study using purposive sampling method. The participants were particularly from the coordinating office, finance and administration, planning \& budgeting coordinating office. The tool for collecting the data for the study was based on non-standard interview with officers that are experts on the topic at the districts and total of Eighteen (18) District Assemblies out of Twenty-Two (22) were covered in Western Region. With regards to the interview conducted, the object for the inquiry was to a large extent to look at the awareness level of green procurement at the district assemblies in Western Region in Ghana. As Guest, Bunce \& Johnson (2006) put it, there are no guidelines for determining nonprobabilistic sample sizes and are virtually nonexistent. The number of interview conducted was based on saturation (ibid) where, by the 17th and 18th interview, no new information or themes were observed in the data. All interviews were tape recorded and transcribed and notes were taken in addition where necessary. The notes and the tape records (transcribed) were reviewed, interpreted the data obtained and were analysed by summarising and comparing the views of the participants.

\section{Findings and Discussion}

This section presents in entirety the main findings and analysis of data gathered from the field.

The interview as stated was non-standardised. Three specific issues were covered: identifying the nature of key legislature, standard and regulation of green procurement regulation at the district assemblies in Ghana, to also look at the level of awareness of green procurement at the district assemblies, and lastly to examine the challenges facing district assemblies in the awareness creation of green procurement practices in Ghana. On the demography of the participants, majority were males with the majority of the participants have also worked with the assemblies for more than 5-10 years and were knowledgeable and had experience enough to provide the relevant information about the districts in relation to the variables of the study.

\subsection{The Nature of Key Legislature, Standards and Regulations of Green Procurement}

With the discussion on key legislation, standard and regulation regulating green procurement at the assemblies, it was revealed that, there are key legislations, standards and regulations regulating assemblies' activities on the environment and the society. The discussion showed key legislations both old and new fashioned to act as green law for instance, in 1901, the Wild Animals Preservation Ordinance, Rivers Ordinance in 1903. Forest reservation was initiated in 1907, followed a year later by the establishment of the Forestry Department. The Mining Rights Regulations Ordinance was introduced in 1925. The Land Planning and Soil Erosion Ordinance was passed in 1953, and amended in 1957 (Benneh, 1985). There is also enactment of Environmental Protection Agency Act, 1994 (Act, 490) which created the corporate body called the Environmental Protection Agency (EPA), there also National Environmental Policy (2012), Environmental Assessment Regulations, LI 1652 (1999), Ghana National Cleaner Production Centre (GNCPC) (2012), National Climate Change Policy (2013), Strategic National Energy Plan (2006) and National Energy Policy (2010) among others. But there is no specific 
law title green procurement. On the issue of district assemblies exercising deliberate legislative and executive functions on the environment, the conclusion was that they exercise deliberate legislative and executive functions at the district when they cited Local Governance Act, 936, (2016) section 12 subsection (3) without limiting subsections (1) and (2), a district assembly shall (f) be responsible for the development, improvement and management of human settlements and the environment in the district. This is indicative of the powers of the district assemblies in protecting their environment and which they confirmed they are enforcing the law with the help of other agencies and ministries and particularly EPA through the use of EPA -Environmental Protection Agency Act, 1994 (Act 490) where they act in liaising and co-operation with government agencies, District Assemblies and other bodies and institutions to control pollution and generally protect the environment.

On the prescription of guidelines in relating to environmental management, it was established that EPA is responsible for regulating the environment and to ensure the implementation of government's policy on the environment thereby become the leading public body for protecting and improving the environment in Ghana and has regulatory and enforcement roles. The participants were clear on the role of their assemblies in environmental management as defined both in the Local Government Act, 1993 (Act 423) and the Environmental Protection Agency Act, 1994 (Act 490) as: "District Assemblies will be the organ through which national policies and programs on environment will be translated into action at the local and district levels and that their action programs will serve as vehicles for creating awareness at the grassroots level". It was also established that the assemblies have been liaising with EPA and the districts with their bye-laws to support EPA in guiding and protecting the environment at the various districts assemblies (Ministry of Local Government and Rural Development Environmental Sanitation Policy 2001, subsection 7.2). It was revealed from the discussion that per the bye-laws and cooperation with other agencies responsible in protecting and maintaining the environment, the districts ensure sound management of natural resources and adequately protect humans, animals and plants against harmful impact and destructive practices. The study as well revealed that the districts with collaboration with other ministries and agencies integrate environmental considerations in sectoral structural and socio-economic planning at the district (Ministry of Lands and Natural Resources Environmental and Social Management Plan (ESMP), 2013).

\subsection{The Level of Awareness of Green Procurement at the District Assemblies}

On the discussion on whether environmental issues at the districts has increased the awareness level of green procurement, where majority were affirmative that the local assemblies are on awareness creation campaigning on sustainable procurement which has been included in Public Procurement Amendment Act 914 (2016) to incorporate detail the social, economic and environmental issues when procuring. The Amendment Act 914 addresses weakness in Act 663 and introduces new procurement policies such as SPP. That is to mainstream relevant issues in stand-alone social and environmental laws into procurement law to ensure the infusion of SPP issues into existing procurement processes. Act 914 amended section 2 (object of PPA) of Act 663 by the insertion of environmentally and socially sustainable after non-discriminatory (Public Procurement Authority: Electronic Bulletin May-Jun 2017). On whether the activities of the citizens and the assemblies at the districts have increased their level of awareness of green procurement at the district assemblies, the participants agreed that the current environmental challenges and management activities in Ghana from major mining companies to small scale mining firms to 'galamsey' to lumber from both the government and the citizenry are becoming conscious of the need to find a better solution to the problem. The discussion cited certain policies like the SPP in the Amended Act 914, Ghana: Green industry and trade assessment, Ghana Environmental Reform Policy (2014), National Climate Change Policy (2013) among others are educating, informing and creating awareness.

On district assemblies organizing programs to enhance awareness creation for staff to boast green procurement knowledge in the district assembly, the discussion established that there are different ministries, agencies and organisations organizing various capacity training to boast staff awareness and understanding of sustainable development through the use of sustainable procurement. The participants cited some instances where there has been capacity training for members and other stakeholders-Joint Evaluation of the Global Environment Facility - GEF Small Grants Programme (2007) where the Small Grants Programme-SGP undertakes national capacity-building workshops twice a year targeted at community-based organisations - $\mathrm{CBOs}$ in vulnerable areas, environmental NGOs, district-level public service providers, assembly members, and policy makers. The collaboration between the district assemblies and the EPA extend to education of the assemblies on awareness creation of managing and protecting the environment. On the top management support for awareness creation of green procurement, the discussion established that government's vision in connection with the developmental agenda is what influence the assemblies' day to day activities and there their major support come from the state-government. A noteworthy body of research indicates that government pressure is a major driver for a 
company's environmental efforts (Walker et al., 2008; Adetunji et al., 2008). Extant literature show that government plays a leading role in driving environmental sustainability into the procurement process. This could be done by creating the opportunity in the form of procurement legislature and laws that allow for environmental sustainability to be incorporated into the procurement process for implementation at the district level. The finding agrees with sustainable procurement policy plan where the government through PPA is taking the lead in supporting and promoting environmental friendly practices through more proactive environmental legislature and training. On whether the policies and programs implemented by the government are helping in increasing the awareness level of green procurement at the district assembly, the participants agreed to the question. The discussion cited some laws or policies covering the environment and its activities in Ghana-National Environmental Policy (2012), Environmental Protection Agency Act, 1994 (Act 490), Environmental Assessment Regulations, LI 1652 (1999), Ghana National Cleaner Production Centre (GNCPC) (2012), National Climate Change Policy (2013) among others are all assisting in creating awareness and protect the environment.

\subsection{Challenges of Awareness Creation of Green Procurement Practices at the District Assemblies}

On the discussion of challenges bordering the assemblies on awareness of green procurement, the participants were positive that there are a lot of challenges, key among them is the assemblies' lack of understanding of what green procurement is and even the name/title is not common among the participants from the conversation, this confirms the studies of Souran \& Sohai (2017), Mensah \& Ameyaw (2012). It was also realised from the discussion that the lack of the understanding encompasses also on how to incorporate environmental issues into buying (public procurement) therefore affecting the assemblies in their awareness creation of GP. This as well backs Cooper et al. (2000) studies that procurement officers are unsure of how to incorporate environmental issues in their buying. The lack of understanding about green procurement is not only existing among practitioners but also amongst other key stakeholder institutions involved in protecting the environment. The study also found out that there is lack of trained staff involving in public procurement at the assemblies and therefore influencing the awareness level of green procurement negatively at the District Assemblies and this is a confirmation of Nasiche \& Ngugi (2014) study on determinants of adoption of green procurement in the public sector. It's also a validation of the findings of Verhage, Gronden, Awanyo \& Boateng (2002) on Ghana lacking of qualified procurement staff in achieving the objectives of the public procurement policy. This supports as well the findings of Gelderman et al.'s (2006) on educating and training purchasers. Advance training in the area of procurement and its innovation is therefore a requirement to overcome major obstacles in using public procurement as a policy tool (Bowen et al., 2001; Walker \& Phillips, 2006). On the question of no specific rule or law on green procurement, the participants were not entirely in agreement with the question simply because there are other laws, regulations, policies or acts that functioned in the same way as green procurement will have done, though they settled on the fact that there is no specific title/name called green procurement in the Public Procurement Act. Even the environmental elements included in the Public Procurement Act 663/914 are not obviously clear and in many case their interpretation is subjective. The study identified one other challenge during the discussion that the significant impact of public procurement as a policy instrument on environment appeared not to be clear to the assemblies. Though green procurement has emerged in the advance nations as a powerful tool in dealing with protecting the environment, its visibility lacks presence in the developing nations like Ghana. This is a validation of Lundberg, Marklund \& Strömbäck (2015) study that there is a general lack of studies within the field of economics that evaluate GPP as an instrument of environmental policy and therefore theoretical finding is that the potential of green procurement to function as an objective effective instrument of environmental policy is limited.

\section{Summary of Findings}

On the nature of key legislature, standard and regulation of green procurement the study established that, there are key legislations, standards and regulations regulating assemblies' activities on the environment and the society, but there is no specific law titled green procurement. It was also revealed that the district assemblies exercising deliberate legislative and executive functions at the district in dealing with the environment. On the prescription of guidelines in relating to environmental management, it was revealed that EPA is responsible for regulating the environment and to ensure the implementation of governments policy on the environment thereby become the leading public body for protecting and improving the environment in Ghana and has regulatory and enforcement roles. The role of the assemblies in environmental management is defined both in the Local Government Act, 1993 (Act 423) and the Environmental Protection Agency Act, 1994 (Act 490) and the assemblies have been liaising with EPA and the districts with their bye-laws to support EPA in guiding and protecting the environment at the various districts assemblies. It was as well established that per the bye-laws and cooperation with other agencies responsible in protecting and maintaining the environment the districts 
ensure sound management of natural resources and adequately protect humans, animals and plants against harmful impact and destructive practices. The study as well revealed that the districts with collaboration with other ministries and agencies integrate environmental considerations in sectoral structural and socio-economic planning at the district.

With the level of awareness of green procurement at the district assemblies, the study established that the districts have increased the level of awareness creation of green procurement through sustainable procurement which has been included in the Public Procurement Amendment Act 914. The district assemblies have also been organizing programs to enhance awareness creation for staff to boast green procurement knowledge in the district assembly. There is also collaboration between the district assemblies and the EPA to extend the education of the assemblies on awareness creation of managing and protecting the environment. On the top management support for awareness creation of green procurement the discussion established that government's vision in connection with the developmental agenda is what influence the assemblies' day to day activities and there their major support comes from the state-government. The finding agrees with sustainable procurement policy plan where the government through PPA is taking the lead in supporting and promoting environmental friendly practices through more proactive environmental legislature and training. On whether the policies and programs implemented by the government are helping in increasing the awareness level of green procurement at the district assembly, the participants agreed to the question. The discussion cited some laws or policies covering the environment and its activities in Ghana-National Environmental Policy (2012), Environmental Protection Agency Act, 1994 (Act 490), Environmental Assessment Regulations, LI 1652 (1999) Ghana National Cleaner Production Centre (GNCPC) (2012), National Climate Change Policy (2013) among others are all assisting in creating awareness and protect the environment.

On the challenges of awareness creation of green procurement practices at the district assemblies, the study established lack of understanding of what green procurement is and even the name/title is not common among the participants from the conversation. The study also found out that there is lack of trained staff involved in public procurement at the assemblies and therefore influencing the awareness level of green procurement negatively at the District Assemblies. On the question of no specific rule or law on green procurement, the participants were not entirely in agreement with the question simply because there are other laws, regulations, policies or acts that functioned in the same way as green procurement will have done. The study also identified that the significant impact of public procurement as a policy instrument on environment appeared not to be clear to the assemblies.

\section{Conclusion}

The motive behind this study is an attempt to create awareness of that part of public procurement as environmental policy instrument and its capacity in protecting and create sustainable environment. The study looks at the awareness level of green procurement at the district assemblies in the Western Region of Ghana and concludes that there is no specific law title green procurement but there are key legislations, standards and regulations regulating assemblies' activities on the environment and the society. It was refreshing to establish that there are several activities through the districts, government and other agencies in creating the awareness of the effects of environmental degradation and a major policy introduction in that direction is the Public Procurement Amendment Act 914 introducing sustainable procurement. The collaboration between the district assemblies and the EPA to extend the education of the assemblies on awareness creation of managing and protecting the environment is very crucial in the step of sustaining the environment. Though the study concludes that there was that lack of understanding of what green procurement is, in itself does not stop the districts from working to protect the environment. The revelation that there is lack of trained staff involving in public procurement at the assemblies is very serious setback in the utilization of public procurement as environmental policy or socioeconomic policy instrument. The findings at this stage suggest that green procurement is not popular concept within the district assemblies in Ghana as a nation and the results should guide policymakers/management to address the issue of creating awareness of green procurement at the district assemblies with a more comprehensive targeted approach and design of accurate measures for implementation of public procurement as an environmental policy instrument.

Although the findings could be applied in many cases, the study is limited by its few participants and from one specific region (Western Region of Ghana) and thus make it is difficult to generalise the findings. However, the legislation for the governance of the district assemblies is one for all and the researchers believed that the findings and its recommendations can be targeted to improve on the awareness level of green procurement in Ghana and the benefits that can be accrued from such a practice. 


\section{Recommendations}

Based on the findings and conclusion, the researchers made the following recommendations.

The current Public Procurement Act 663 or its Amendment Act 914 does not specifically mention green procurement. The researchers therefore recommend that the procurement policy and the Act 663/914 should be reformed to reflect green procurement to help the districts in their quest in creating sustainable environment.

The district assemblies and EPA should organise joint seminars and workshops to sensitize and create awareness among the assembly's staff on the benefits of green procurement and the need to adopt it.

The assemblies and EPA should also link up to train their supply/logistics/procurement practitioners and the other staff of the assemblies to understand green procurement and its associated benefits. When education and training is very much tied to the environmental regulations and the policy, practitioners involved in operative ordering most likely will be aware of green procurement's impact on the environment and they may presume to use. This will improve awareness and knowledge with green procurement processes amongst practitioners and staff employed in the assemblies.

Finally, the Assemblies should involve all stakeholders in taken strategic decision regarding the effective and efficient awareness creation of green procurement to aid in creating the sustainable environment we crave for.

The researchers recommend a further study into awareness level of green procurement at the district assemblies in Ghana from the suppliers' perspective so that they could also contribute meaningfully to sustainable procurement.

\section{References}

Adetunji, I., Price, A. D. F., \& Fleming, P. (2008). Achieving Sustainability In the Construction Supply Chain: Proceedings of the Institution of Civil Engineering: Engineering Sustainability. https://doi.org/10.1680/ensu.2008.161.3.161

Agyepong, G. T. (1987). Perspectives on Land Resource Planningfor Conservafion in Ghana. Report of National Conference on Resource Conservation for Ghana's Sustainable Development, EPC, Accra.

Alliance for Development. (2014). Ghana and Sustainable Development: Restoring the Present, Securing the Future.

Retrieved

from

http://www.myjoyonline.com/opinion/2014/February-24th/ghana-and-sustainable-development-restoring-th e-present-securing-the-future.php

Ashenbaum, B. (2008). The Global Sourcing and Logistics Exercise: A Group Exercise to Demonstrate Basic Global Supply Chain Principles. Decision Sciences Journal of Innovative Education, 6(2), 355-364. https://doi.org/10.1111/j.1540-4609.2008.00180.x

Ayarkwa, J., Ayirebi-Danso, \& Amoah, P. (2010). Barriers to Implementation of EMS in Construction Industry in Ghana. International Journal of Engineering Science. Forum, Commonwealth Local Government.

Benneh G. (1985). Population, disease and rural development programme in the Upper East Rcgion of Ghana. In J. I. Clark et al. (Eds.), Population and Development Projects in Africa (pp. 206-218). Cambridge: Cambridge University Press. https://doi.org/10.1017/CBO9780511898402.016

Benneh, G., \& Agyapong, G. T. (1990). Land degradation in Ghana. London: Commonwealth Secretariat, and Legon, Department of Geography and Resource Development, University of Ghana.

Björklund, M. (2011). Influence from the business environment on environmental purchasing Drivers and hinders of purchasing green transportation services. Journal of Purchasing and Supply Management, 17(1), 11-22. https://doi.org/10.1016/j.pursup.2010.04.002

Blome, C., Hollos, D., \& Paulraj, A. (2013). GP and green supplier development: antecedents and effects on supplier performance. International Journal of Production Research, 52(1), 32-49. https://doi.org/10.1080/00207543.2013.825748

Bobis, V., \& Staniszewski, J. (2009). Making the Case for Sustainable "Green" Procurement. Retrieved from www-935.ibm.com/services/us/gbs/bus/pdf/sustainable_procurement_bobis_staniszewski.pdf

Bohari, M. A. A. (2015). Developing Green Procurement Framework for Construction Projects in Malaysia, Conference: The 6th International Conference on Engineering, Project, and Production Management (EPPM2015), At Surfers Paradise Marriott Resort \& Spa, Gold Coast, Qld.

Bouwer, M., Jonk, M., Berman, T., Bersani, R., Lusser, H., Nappa, V., ... Viganò, C. (2006). Green public 
procurement in Europe 2006-conclusions and recommendations. Virage Milieu \& Management by, KorteSpaarne 31, 2011 AJ Haarlem, the Netherlands. Retrieved form http://ec.europaeu/environment/gpp/pdf/take_5.pdf

Bowen, F. E. (2000). Environmental Visibility: A Trigger of Green Organizational Response? Business Strategy $\begin{array}{llll}\text { and the } \quad \text { Environment, } & 92-107 .\end{array}$ https://doi.org/10.1002/(SICI)1099-0836(200003/04)9:2<92::AID-BSE230>3.0.CO;2-X

Bowen, F. E., Cousins, P. D., Lamming, R. C., \& Faruk, A. C. (2001). The role of supply management capabilities in green supply. Production and Operations Management, 15(2), 63-75. http://dx.doi.org/10.1111/j.1937-5956.2001.tb00077

Bryde, D., \& Meehan, J. (2011). Sustainable procurement practice. Business Strategy and the Environment, 20(2), 94-106. https://doi.org/10.1002/bse.678

Bryman, A. (2001). Social Research Methods. Oxford: Oxford University Press.

Carter C. R., \& Dresner M. (2001). Purchasing's Role in Environmental Management: Cross-Functional Development of Grounded Theory. Journal of Supply Chain Management, 37(3), 12-27. https://doi.org/10.1111/j.1745-493X.2001.tb00102.x

Chartered Institute of Purchasing and Supplies-CIPS. (2009). Sustainable procurement. Retrieved from www.cips.org/Documents/Resources/Knowledge Summary/Sustainable Procurement.pdf

Chien, M. K., \& Li-Hsing, S. (2007). An empirical study of the implementation of green supply chain management practices in the electrical and electronic industry and their relation to organizational performances.

Cooper, R., Frank, G., \& Kemp, R. (2000). A multinational comparison of key ethical issues, helps and challenges in the purchasing and supply management profession: the key implications for business and the professions. Journal of Business Ethics, 23, 83-100. https://doi.org/10.1023/A:1006279112858

Darko-Mensah, A. B., \& Okereke, C. (2013). Can environmental performance rating programmes succeed in Africa? An evaluation of Ghana's AKOBEN project. Management of Environmental Quality: An International Journal, 24(5), 599-618. https://doi.org/10.1108/MEQ-01-2012-0003

Fields, C., \& Haver, R. (2008). Challenges to Military Operations in Support of US National Interests. Volume 1: Executive Summary (Defense Science Board 2007 Summer Study).

Gattiker, T. F. (2008). Supply Management's strategic Role in Environmental Practices. Centerfor Advanced Purchasing Studies.

Gelderman, J. C., Ghijsen, W. P., \& Brugman, J. M. (2006). Public procurement and EU tendering directives-explaining non-compliance. International Journal of Public Sector Management, 19(7), $702-714$. https://doi.org/10.1108/09513550610704716

Green Procurement in Kenyan Hospitals. (2012). Exploring the awareness and opportunities for Kenyan hospitals to implement green procurement.

Grönroos, C. (2006). On defining marketing: finding a new roadmap for marketing. Marketing Theory, 6(4), 395-417. https://doi.org/10.1177/1470593106069930

Guest, G., Bunce, A., \& Johnson, L. (2006). How many interviews are enough? An experiment with data saturation and variability. Field Methods, 18(1), 59-82. https://doi.org/10.1177/1525822X05279903

Jaillon, L., Poon, C. S., \& Chaing, Y. H. (2009). Quantifying the Waste Reduction Potential of Using Prefabrication in Building Construction in Hong Kong. Waste Mangement, 29, 309-320. https://doi.org/10.1016/j.wasman.2008.02.015

Kalubanga, M. (2012). Sustainable Procurement: Concept, and Practical Implications for the Procurement Process. International Journal of Economics and Management Sciences, 1(7), 1-7.

Lundberg, S., Marklund, P., Strömbäck, E., \& Sundström, D. (2015). Using Public Procurement to Implement Environmental Policy. An Empirical Analysis. Environmental Economics and Policy Studies. Online first.

Lysons, K., \& Farrington, B. (2012). Purchasing and Supply Chain Management (8th ed.). London: Pearsons.

Maignan, I., Hillebrand, B., \& McAlister, D. (2002). Managing socially -responsible buying: how to integrate noneconomic criteria into the purchasing process. European Management Journal, Nr. 20(6), 641-648. https://doi.org/10.1016/S0263-2373(02)00115-9 
Menguc, B., Auh, S., \& Ozanne, L. (2010). The interactive effect of internal and external factors on a proactive environmental strategy and its influence on a firm's performance. Journal of Business Ethics, 94(2), 279-298. https://doi.org/10.1007/s10551-009-0264-0

Mensah, S., \& Ameyaw, C. (2012). Sustainable procurement: the challenges of practice in the Ghanaian construction industry. In S. Laryea, S. A. Agyepong, R. Leiringer, \& W. Hughes (Eds.), Procs 4th West Africa Built Environment Research (WABER) Conference, 24-26 July 2012, Abuja, Nigeria, 871-880.

Ministry of Lands and Natural Resources. (2013). Environmental and Social Management Plan (ESMP) Final Report. $\quad$ Retrieved from http://www.fcghana.org/userfiles/files/redd/ESMP\%20Ghana\%20FIP_Final\%20Report.pdf

Ministry of Local Government and Rural Development. (2001). Environmental Sanitation Policy 2001, subsection 7.2.

Ministry of the Environment. (2012). Guidelines for Green Procurement Promotion (Provisional edition)-Promotion of value chain management. Retrieved from www.env.go.jp/en/policy/economy/pecba/aemuei_201203_ref1.pdf

Nasiche, F., \& Ngugi, G. K. (2014). Determinants of adoption of green procurement in the public sector: A case study of Kenya Pipeline Company. International Journal of Social Sciences and Entrepreneurship, 1(11), 351-372.

Nderitu, K. M., \& Ngugi, K. (2014). Effects of Green Procurement Practices on An Organization Performance In Manufacturing Industry: Case Study Of East African Breweries Limited. European Journal of Business Management. Retrieved from http://ku.ac.ke/schools/business/images/stories/research/dr_ngugi/pdf

Odeen, P. A., \& Howard, W. G. (2008). The Defense Science Board 1998 Summer Study Task Force on DoD Logistics Transformation. Volume 1: Final Report. DEFENSE SCIENCE BOARD.

OECD. (2012). Green Growth and Developing Countries. A Summary for Policy Makers.

OECD. (2014). Smart Procurement Going green: best practices for green procurement-CANADA. Retrieved from www.oecd.org/governance/procurement/toolbox/search/gpp-procurement-Canada.pdf

Poon, C. S., Yu, A. T., \& Jaillon, L. (2004). Reducing Building Waste at Construction Sites in Hong Kong. Construction Management and Economics, 22(5), 461-470. https://doi.org/10.1080/0144619042000202816

Procurement \& Fiduciary Services Department (ORPF) African Development Bank. (2014). Comprehensive Review of the AFDB's Procurement Policies and Procedures Summary of Literature on Sustainable/ Green Public Procurement (www.afdb.org).

Public Procurement (Amendment) Act, 2016 (Act 914).

Public Procurement Act, 2003 (Act 663).

Sarkis, J., \& Tamarkin, M. (2005). Real options analysis for "green trading": the case of greenhouse gases. The Engineering Economist, 50(3), 273-294. https://doi.org/10.1080/00137910500227208

Saunders, M. (1997). Strategic Purchasing \& Supply Chain Management (2nd ed.). Pearsons Education Center: England.

Sharma, S. (2000). Managerial Interpretations and Organizational Context as Predictors of Corporate Choice of Environmental Strategy. Academy of Management Journal, 43(4), 681-697. https://doi.org/10.2307/1556361

Shittu, E., \& Bake, E. (2010.). Optimal Energy R\&D Portfolio Investments in Response to a Carbon Tax. IEEE Transactions on Engineering Management, 57(4), 547-559. https://doi.org/10.1109/TEM.2009.2023107

Sourani, A., \& Sohail, M. (2011). Barriers to addressing sustainable construction in public procurement strategies. Proceedings of the Institution of Civil Engineers in Engineering Sustainability, 164(4), 229-237. https://doi.org/10.1680/ensu.2011.164.4.229

UNDP Practice Series. (2008). Environmental Procurement Practice Guide. Retrieved from www.ungm.org/Areas/Public/Downloads/UNDP_Guide.pdf

UNEP. (2011). Green Economy Report: Towards A Green Economy: Pathways to Sustainable Development and Poverty Eradication. Retrieved from www.unep.org/greeneconomy

United Nations Department of Economic and Social Affairs Division for Sustainable Development. (2008). 
Public Procurement as a tool for promoting more Sustainable Consumption and Production patterns. Retrieved from sustainabledevelopment.un.org/content/documents/no5.pdf

United Nations Development Programme. (1999). Global Environment Outlook. UNEP.

Unomaha. (2016). University of Nebraska at Omaha Stars Report. Retrieved from www.unomaha.edu/sustainability/_docs/SILVER_university-of-nebraska-at-omaha-ne.pdf

Verhage, R., Gronden, J. V. D., \& Boateng, S. (2002). The challenge of integrating sustainability into talent and organization strategies: investing in the knowledge, skills and attitudes to achieve high performance. Corporate Governance, 9(4), 484-494.

Walker, H., \& Brammer, S. (2011). Sustainable procurement in the public sector: an international comparative study. International Journal of Operations \& Production Management, 31(4), 452-476. Bingley: Emerald Publishing Group Limited. https://doi.org/10.1108/01443571111119551

Walker, H., \& Brammer, S. (2012). The relationship between sustainable procurement and e-procurement in the public sector. International Journal of Production Economics, 140(1), 256-268. https://doi.org/10.1016/j.ijpe.2012.01.008

Walker, H., \& Phillips, W. (2006). Sustainable procurement: Emerging issues. In International Public Procurement Conference: Proceedings 21-23 September 2006, Rome, Italy.

Walker, H., Di Sistob, L., \& Mcbainc, D. (2008). Drivers and Barriers to Environmental Supply Chain Management Practices: Lessons from the Public and Private Sectors. Journal of Purchasing and Supply Management, 14(1), 69-85. https://doi.org/10.1016/j.pursup.2008.01.007

Yeboah K., \& Mensah, T. A. A. (2014). 40 Years of environmental protection in Ghana: Footprints from EPC to EPA.

\section{Copyrights}

Copyright for this article is retained by the author(s), with first publication rights granted to the journal.

This is an open-access article distributed under the terms and conditions of the Creative Commons Attribution license (http://creativecommons.org/licenses/by/4.0/). 